\title{
Sensitive Electrochemical Determination of Folic Acid Using ex-situ Prepared Bismuth Film Electrodes
}

\author{
Nives Vladislavić, ${ }^{1, *}$ Marijo Buzuk, ${ }^{1}$ Maša Buljac, ${ }^{2}$ Stjepan Kožuh, ${ }^{3}$ Marija Bralić, ${ }^{2}$ Slobodan Brinić ${ }^{1}$
}

\author{
1 Faculty of Chemistry and Technology, Department of General and Inorganic, Chemistry, University of Split, Split, Croatia \\ 2 Faculty of Chemistry and Technology, Department of Environmental Chemistry, University of Split, Split, Croatia \\ 3 Faculty of Metallurgy, University of Zagreb, Sisak, Croatia \\ * Corresponding author's e-mail address: nives@ktf-split.hr
}

RECEIVED: Mary 12, 2017 * REVISED: June 30, 2017 * ACCEPTED: June 30, 2017

THIS PAPER IS DEDICATED TO PROF. MIRJANA METIKOŠ-HUKOVIĆ ON THE OCCASION OF HER BIRTHDAY

Abstract: The electrochemical behavior of folic acid (FA), at the electrochemically prepared ex situ bismuth film (BiF) on glassy carbon electrode, clearly indicates electrocatalytic nature of the prepared film toward FA reduction (at $-0.55 \mathrm{~V}$ ). Scanning electron microscopy is used for morphological characterization of the prepared BiF. Accordingly, we establishing an electrochemical procedure based on square wave cathodic stripping voltammetry, preceded by accumulation of FA on the BiF electrode (BiFE). This analytical method is optimized and its analytical performance is presented. This electrode displays a two linear response range: 0.1 to $1.0 \mu \mathrm{mol} \mathrm{L}^{-1}$ and $1.0-10.0 \mu \mathrm{mol} \mathrm{L}^{-1}$ with sensitivity of $20.10 \mu \mathrm{A} \mathrm{mol}^{-1} \mathrm{~L}$ and $2.28 \mu \mathrm{A} \mathrm{mol}^{-1} \mathrm{~L}$, respectively. Developed method was validated in compliance with spectrophotometric method. Excellent recovery and standard deviation obtained with BiFE revealed great analytical potential of the proposed method which was applied for the determination of FA in pharmaceuticals formulation.

Keywords: bismuth film, folic acid, voltammetry, electroanalytical.

\section{INTRODUCTION}

$\mathbf{F}$ OLIC ACID (FA), N-(4-\{[(2-amino-4-oxo-1,4-dihydropteridin-6-yl)methyl]amino\} benzoyl)-L-glutamic acid, pteroyl-L-glutamic acid) belongs to the B-vitamin group also referred as vitamin $\mathrm{M}$, vitamin $\mathrm{B}_{9}$ (commonly called folate), vitamin $B_{c}$ (or folacin). As it cannot be synthesized in body it must be supplied daily from the foods such as fruits, vegetables, mushrooms, algae, fortified grains, etc. ${ }^{[1]}$ In food FA predominantly exist as polyglutamates, which have to be hydrolyzed in body to monoglutamates in order to be transported. Folate, as conjugate base of FA, represents active form which is incorporated in many metabolic pathways, mainly in carbon transfer reactions, such as amino acid interconversions and purine and pyrimidine biosynthesis. [2] Also, it has important role in homocysteine metabolism. However, synthetic $\mathrm{B}_{9}$-vitamin (in dietary supplements or in fortified food) is in the form of folic acid, which is most stable form, ${ }^{[3]}$ and in human body FA is transformed into its active form by the enzyme dihydrofolate reductase.

As consequence of low folates intake, numbers of health disorders were reported: neural tube defect, coronary heart diseases and osteoporosis, increased risk of breast and colorectal cancer, poor cognitive performance, hearing loss, anemia.

Although FA represents most stabile form among the group of "folates", it will be decomposed in the presence of the oxidizing and reducing agents, in alkaline or acidic medium, as well as it is exposed to UV light. [4]

Due to importance of FA in human health, methods for its determination have been received increasing interest Beside traditional microbiological methods, based on Lactobacillus rhamnosus, other analytical methods have been proposed for the detection and quantification of folic acid such as: high-performance liquid chromatography 
(HPLC) combined with UV detection, ${ }^{[5,6,7,8]}$ ion-pair based liquid chromatography (IP-LC) using mass spectroscopy, ${ }^{[9,10]}$ capillary electrophoresis with mass spectrometry, ${ }^{[11]}$ UV spectrophotometer, ${ }^{[12]}$ flow injection chemiluminescence, ${ }^{[13]}$ commercially available enzyme-linked immunosorbent assay (ELISA) test and fluorometric method. ${ }^{[14]}$ However, some of the above mentioned methods are nonspecific and laborious, also needed harmful and expensive substances which in combination with long-time sample preparation and well-trained operators drastically increased the time and cost of analysis.

As disposable tool for reliable, rapid, accurate, simple, fast and low-cost determination of FA, various electrochemical techniques have been introduced. Reported electrochemical techniques, used in determination of FA, together with various surface modification techniques and analytical performance were summarized by Mirmoghtadaie et al. ${ }^{[15]}$ Review reveals that besides all electrochemical techniques, voltammetry (square wave, differential pulse or stripping) is commonly used electrochemical technique. Although using of hanging mercury drop electrode ${ }^{[16,17,18]}$ or mercury meniscus modified silver solid amalgam electrode ${ }^{[19]}$ have great advantage concerning possibility of preconcentration (adsorption) before stripping thus achieving very low limits of detection, toxicity as well as poor reproducibility limits this methods for further development and application. By using of an "environmentally friendly" electrode material - bismuth (mostly as electrodeposited bismuth film as it is well known resemblance in electrochemical behavior between $\mathrm{Bi}$ and $\mathrm{Hg}$ ) in electrochemical "stripping" analysis, ${ }^{[20,21,22]}$ it is possible to overcome issues related to mercury based materials. Although conventional and micro bismuth film electrodes have been widely used in electrochemical analysis of various organic compounds ${ }^{[23-37]}$ their relevance for folic acid determination has been very poorly exploited. Only Ananthi et al. [38] reported determination of folic acid using glassy carbon electrode modified with an electrodeposited bismuth nanowires by square wave voltammetry. Authors used hydrogen bubbles (electrodeposition was performed at $-0.1 \mathrm{~V}$ in acetate buffer $\mathrm{pH} 4.5$ ) as a "stagnant template" for obtaining the bundles of dendritic compact nanowires of bismuth. This approach resulted in less negative reduction potential and higher electroreduction current, indicating excellent electrocatalytic nature of the prepared nanowires toward FA electroreduction, compared to that on the bare glassy carbon. Furthermore, determination of FA on glassy carbon can be precluded due to the surface fouling effect of the oxidized products of the ascorbic and uric acid as it was reported by Kalimuthu et al. ${ }^{[39]}$ As most of biomolecules present in real sample (e.g. dopamine, uric acid, ascorbic acid) are easily oxidizable, direct reduction of FA represent potential path for resolution of interference problems. Results of our preliminary work ${ }^{[40]}$ indicates that bismuth film prepared under controlled conditions can be used to resolve above mentioned problems.

Based on previously investigation ${ }^{[40]}$ on the relevance of the prepared an ex-situ bismuth film at glassy carbon electrode (BiFE) for the determination of FA, in this work additional optimization of the parameters and procedure are presented. Film has been deposited in presence of a complexing agent (EDTA) to obtain arranged homogenous structure, confirmed with scanning electron microscopy (SEM). Such prepared BiFE was applied for selective adsorption (at chosen potential) of folic acid, followed by its reduction using square wave cathodic stripping voltammetry (SWCSV).

Developed method was validated and confirmed by proposed spectrophotometric method.[41] Developed method was applied in the determination of FA in real samples with excellent selectivity, reliability and accuracy.

\section{EXPERIMENTAL}

\section{Material and Methods}

All solutions were prepared from analytical grade chemicals and were used as received.

For electroanalytical determination: for the preparation of acetic buffer, sodium acetate and acetic acid all purchased from Kemika (Croatia) were prepared by dissolution in double distilled water. Stock solution of the bismuth nitrate $\left(1 \times 10^{-3} \mathrm{~mol} \mathrm{~L}^{-1} \mathrm{Bi}(\mathrm{III})\right)$ was prepared by dissolution of $99.99 \% \mathrm{Bi}\left(\mathrm{NO}_{3}\right)_{3} \times 5 \mathrm{H}_{2} \mathrm{O}$ (Sigma-Aldrich, Inc., USA) in acetate buffer solution (0.1 mol L-1; pH 4.5). The folic acid (ALFA AESAR, Ward Hill, MA, USA) solutions were prepared daily by dissolution of appropriate amount of the FA in acetate solution, previously deaerated with $\mathrm{N}_{2}$.

For spectroscopic measurement: zinc powder, hydrochloric acid, amidosulfonic acid, sodium nitrite and sodium hydroxide all purchased from Kemika (Croatia). 3-aminophenol was obtained from Sigma Aldrich (St. Louis, USA), while potassium dihydrogen phosphate was purchased from Merck KGaA (Darmstadt, Germany). Folic acid $\left(50 \mathrm{mg}\right.$ ) was dissolved in $0.1 \mathrm{~mol} \mathrm{~L}^{-1}$ sodium hydroxide solution. This solution was reduced using zinc and concentrated hydrochloric acid to produce $p$-aminobenzoilglutamic acid ( $p-A B G A)$, filtered and diluted to $100 \mathrm{~mL}$ in a calibrated flask. The aliquot of folic acid (from 0 to $6 \mathrm{ppm}$ FA) are transferred to $25 \mathrm{~mL}$ flask where added $2 \mathrm{~mL}$ of hydrochloric acid $\left(5 \mathrm{~mol} \mathrm{~L}^{-1}\right), 1 \mathrm{~mL}$ of sodium nitrite (1\%), $1 \mathrm{~mL}$ amidosulfonic acid (4\%) and $5 \mathrm{~mL}$ 3-aminophenol (1\%). After obtaining a yellow-orange product, in flask where added $3 \mathrm{~mL}$ of hydrochloric acid $\left(5 \mathrm{~mol} \mathrm{~L}^{-1}\right)$ and flasks is filled up to the mark. The solutions were freshly prepared with deionized water. 
The food supplement (Folacin, Jadran - Galenic Laboratory (JGL), dietary supplement) was purchased from local drug store.

The standard electrochemical cell with saturated calomel electrode (SCE) as reference, Pt plate as auxiliary and $2 \mathrm{~mm}$ in diameter GCE (Metrohm, Herisau, Switzerland) or prepared BiFE as working electrode was used. The stripping measurements were carried out in deoxygenated solutions under pure nitrogen atmosphere. All experiments were carried out at $25{ }^{\circ} \mathrm{C}$, controlled by thermostat (Huber CC1, Offenburg, Germany). All electrochemical measurements were carried out with potentiostat (Autolab PGSTAT 302N), connected to PC and driven by GPES 4.9 Software (Eco Chemie).

For microscopic study, after electrodeposition, BiFEs were rinsed carefully in redistilled water, shortly dried in $\mathrm{N}_{2}$ atmosphere and then transferred to a microscope chamber. The surface morphology of the BiFEs was studied on Vega II LSH (TS 5130 LS) scanning electron microscope (Japan Electron Optics Laboratory, Japan). Obtained image was quantified using ImageJ Program (Rasband, U.S. NIH, Bethesda, Maryland).

A Varian, Cary, UV Visible spectrophotometer with $1.0 \mathrm{~cm}$ matched cells was used for all spectroscopic measurements. Spectroscopic measurements were performed according procedure reported by Nagaraja et al. ${ }^{[41]}$

Our previous studies ${ }^{[0]}$ have revealed that the optimum potential used for electrodeposition of bismuth on glassy carbon electrode is $-0.9 \mathrm{~V} v \mathrm{~s}$. SCE during $600 \mathrm{~s}$. The procedure was carried out ex situ in quiescence solution of acetate buffer $0.1 \mathrm{~mol} \mathrm{~L}^{-1}(\mathrm{pH} 4.5)$ containing bismuth and EDTA, in equal concentrations amounting $1 \times 10^{-3} \mathrm{~mol} \mathrm{~L}^{-1}$.

For electroanalytical determination of FA the best parameters were established by optimization as it is presented in Results and Discussion.

Solution of food supplement (Folacin) was prepared as follows: tablet which contains $5 \mathrm{mg}$ (according to declaration) of active substance - folic acid was dissolved in appropriate amount of water. Such solution was used in further determinations. The exact concentration of this solution was determined by spectrophotometric method according to Nagaraja et al. ${ }^{[41]}$

\section{RESULTS AND DISCUSSION}

\section{SEM Study of Electrodeposited Bismuth Film}

Detail optimization of the preparation procedure for obtaining BiF with satisfying analytical purpose, together with its electrochemical characterization by electrochemical impedance spectroscopy and morphology of the bismuth film electrodeposited on to glassy carbon electrode were

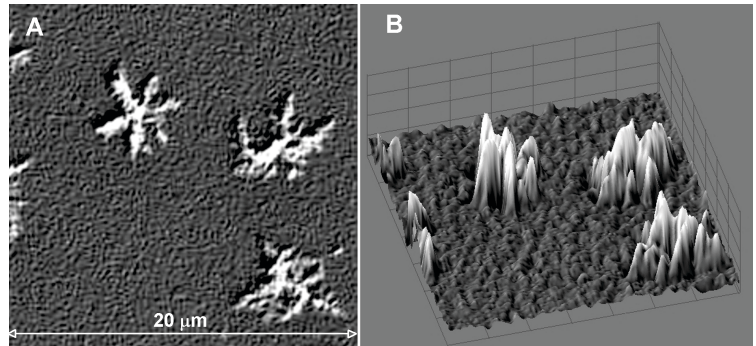

Figure 1. (A) part of SEM image at magnification 3000x of the bismuth particles of film formed in $0.1 \mathrm{~mol} \mathrm{~L}^{-1}$ acetate buffer solution ( $\mathrm{pH} 4.5$ ) containing $1.0 \times 10^{-3} \mathrm{~mol} \mathrm{~L}^{-1} \mathrm{Bi}(\mathrm{III})$ and $1.0 \times 10^{-3} \mathrm{~mol} \mathrm{~L}^{-1}$ EDTA at $-0.9 \vee$ for $60 \mathrm{~s}$; (B) crosssectional view generated from SEM image.

presented by Vladislavić et. al.[40] The micrograph of the optimized BiF, obtained by SEM, revealed that deposited bismuth particles form crystals characterized with large flakes-like dendritic structure (see Figure 1A). The part of formed film was evaluated with ImageJ software. Film thickness $(\delta)$ was assessed by measuring the $z y$ or $z x$ planes of SEM image (Figure 1.A) and by assessing the cross-sectional region of each z-stack image using the "Plot Profile" (Figure 1.B). ${ }^{[42]}$

This approach reveals that the flakes-like bismuth particles have approximately $6 \mu \mathrm{m}$ in diameter and about $10 \mu \mathrm{m}$ in heights. These particles are randomly distributed over the entire surface (with average thickness of $2 \mu \mathrm{m}$ ) that consisted from deposited bismuth. The BiFE with such obtained morphology was applied for electrochemical determination of FA.

\section{Electrochemical Behavior of FA at Prepared BiFEs}

One of the advantages of BiF is high hydrogen overvoltage, which allows good operating cathodic potential. For getting insight of electrochemical behavior of the FA at bare GCE and BiFE, the cyclic voltammetry measurements were performed in wide potential window. However, in anodic branch (around O V vs. SCE) intensive dissolution of BiF was occurred (not shown), which is not plausible if considering mechanism of FA determination presented by Le Gall and van den Berg ${ }^{[18]}$ and Ananthi et al. ${ }^{[38]}$ According to these observations, electrochemical behavior of FA at BiFE and GCE were investigated in potential window between $-0.35 \mathrm{~V}$ and $-0.9 \mathrm{~V}$, in acetate buffer solution. Obtained voltammograms are presented in Figure 2A. As it can be seen, significant changes in cyclic voltammogram in the presence of FA can not be observed. In contrast, voltammetric response of the BiFE in the presence of FA revealed well defined reduction peak around $-0.55 \mathrm{~V}$, which clearly indicate electrocatalytic nature of the prepared BiF toward FA reduction. 

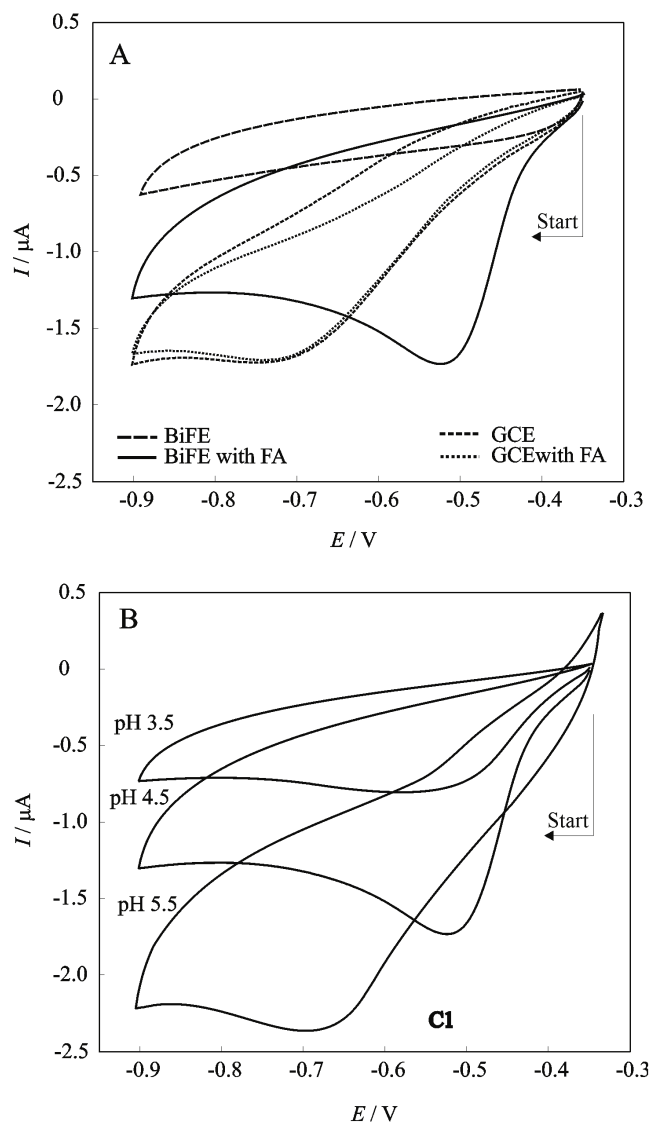

Figure 2. Cyclic voltammograms obtained at: (A) GCE and BiFE in $0.1 \mathrm{~mol} \mathrm{~L}^{-1}$ acetate buffer solution $(\mathrm{pH} 4.5)$ in absence and in presence of $1.0 \times 10^{-4} \mathrm{~mol} \mathrm{~L}^{-1} \mathrm{FA}$ and (B) BiFE in acetate buffer solutions with different $\mathrm{pH}$ in presence of $1.0 \times 10^{-4} \mathrm{~mol} \mathrm{~L}^{-1} \mathrm{FA}$; (scan rate $25 \mathrm{mV} \mathrm{s}^{-1}$ ).

The observed shift of the reduction potential to the less negative values and the increase of FA reduction current on BiFE vs. GCE clearly indicate the electrocatalytic nature of BiFE for this reaction. Such behavior was also observed with BiNWs / GC, and was attributed to high surface / volume ratio of the electrode together with a uniform pore size that facilitates the fast kinetics of the reduction of FA. ${ }^{[38]}$

A proposed reaction mechanism for the reduction of FA in acetic buffer solution is shown in Figure 3, due to reversible reduction of FA to 5,8-dihydrofolic acid, followed by tautomerization to give 7,8-dihydrofolic acid. [17,18]

As it previously reported, pterin part of folic acid can produce a reduction peak at potentials between $-0.5 \mathrm{~V}$ and $-0.8 \mathrm{~V}$, depending on $\mathrm{pH}$, where glutamic acid (part of folic acid) is electroinactive. Based on this information, obtained reduction peak at $-0.55 \mathrm{~V}$ can be attributed to the reduction of nitrogen from pteridine according previously proposed reaction.<smiles>[R]Cc1cnc2nc(N)[nH]c(=O)c2n1</smiles>

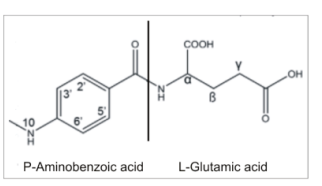

Figure 3. Reaction scheme for the electrochemical reduction of folic acid at pH 4.5 .

By increasing of $\mathrm{pH}$ (Figure $2 \mathrm{~B}$ ) reduction peak of folic acid (C1) increases and shifts toward more negative potentials, which is expected if considering previously proposed reaction. ${ }^{[18]}$ In addition to voltammograms recorded at $\mathrm{pH} 3.5$ and 4.5 , voltammogram recorded at $\mathrm{pH} 5.5$ show increase of oxidation current, probably owning to improved dissolution of the bismuth film. ${ }^{[33]}$ Although higher cathodic current can be observed at $\mathrm{pH} 5.5$, the reduction signal attributed to cathodic reduction of FA is more pronounced at $\mathrm{pH}$ 4.5. Thus, for optimum $\mathrm{pH}$ value 4.5 was chosen.

\section{Optimization of SWCSV Procedure and Quantitative Utility}

The SWCSV procedure has been established by monitoring the influence of applied potential increment $\left(\Delta E_{s}\right)$, frequency $(f)$, and pulse height $\left(\Delta E_{\mathrm{p}}\right)$, accumulation potential $\left(E_{\mathrm{acc}}\right)$ and accumulation time ( $\left.t_{\mathrm{acc}}\right)$ on peak currents $\left(I_{\mathrm{p}}\right)$ and obtained results of the optimization are presented in Figure 4.

The influence of accumulation potential on to reduction current was monitored in the potential range where no reduction of $\mathrm{FA}$ or / and dissolution of the BiF take place. As it can be seen, maximum of the cathodic peak current was obtained at $-0.4 \mathrm{~V}$. Decrease of the reduction current, at more negative accumulation potential of $-0.4 \mathrm{~V}$, can be attributed to the process of reduction of the FA but of the small extent. The increase of the cathodic current with prolonged accumulation time can be observed till $600 \mathrm{~s}$, after changes in current were negligible. According to above, for analytical measurements, folic acid was accumulated for $120 \mathrm{~s}$ in a stirred solution, followed by accumulation for $60 \mathrm{~s}$ in quiescent solutions under nitrogen atmosphere. Effect of $\Delta E_{\mathrm{s}}$ on cathodic current was examined in dependence of the frequency. At frequencies above $30 \mathrm{~Hz}$ signal was strongly influenced by background noise. Also, at high frequencies, shift of the reduction potential toward negative values was observed. Analytical signal at high $\Delta E_{\mathrm{s}}$ values (at 

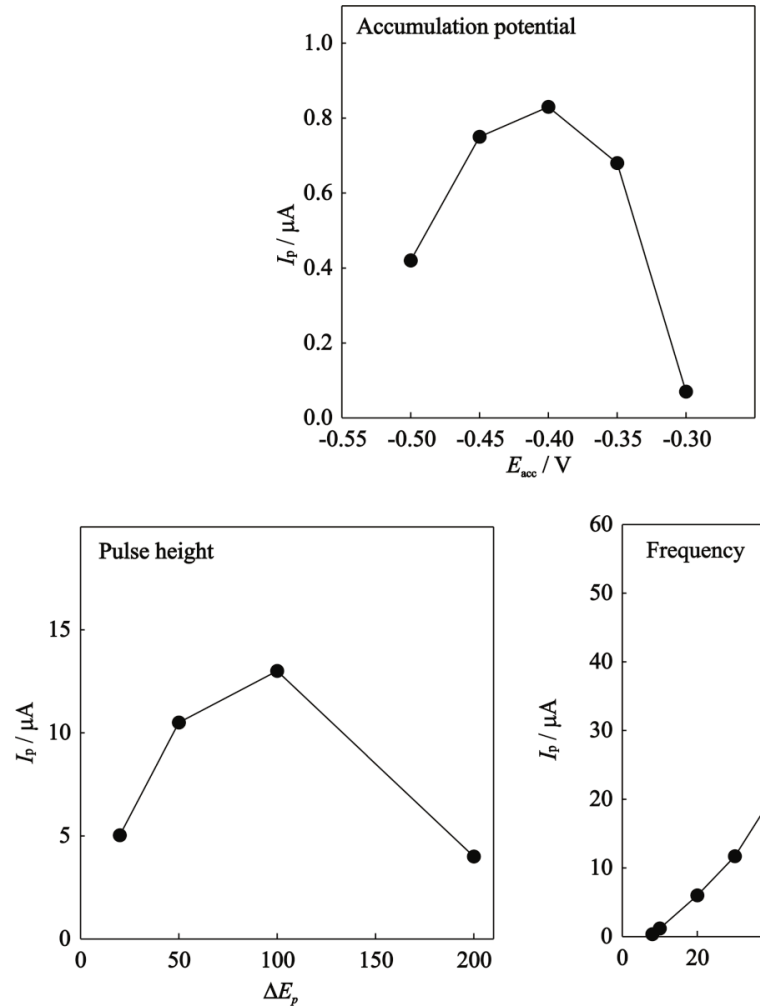
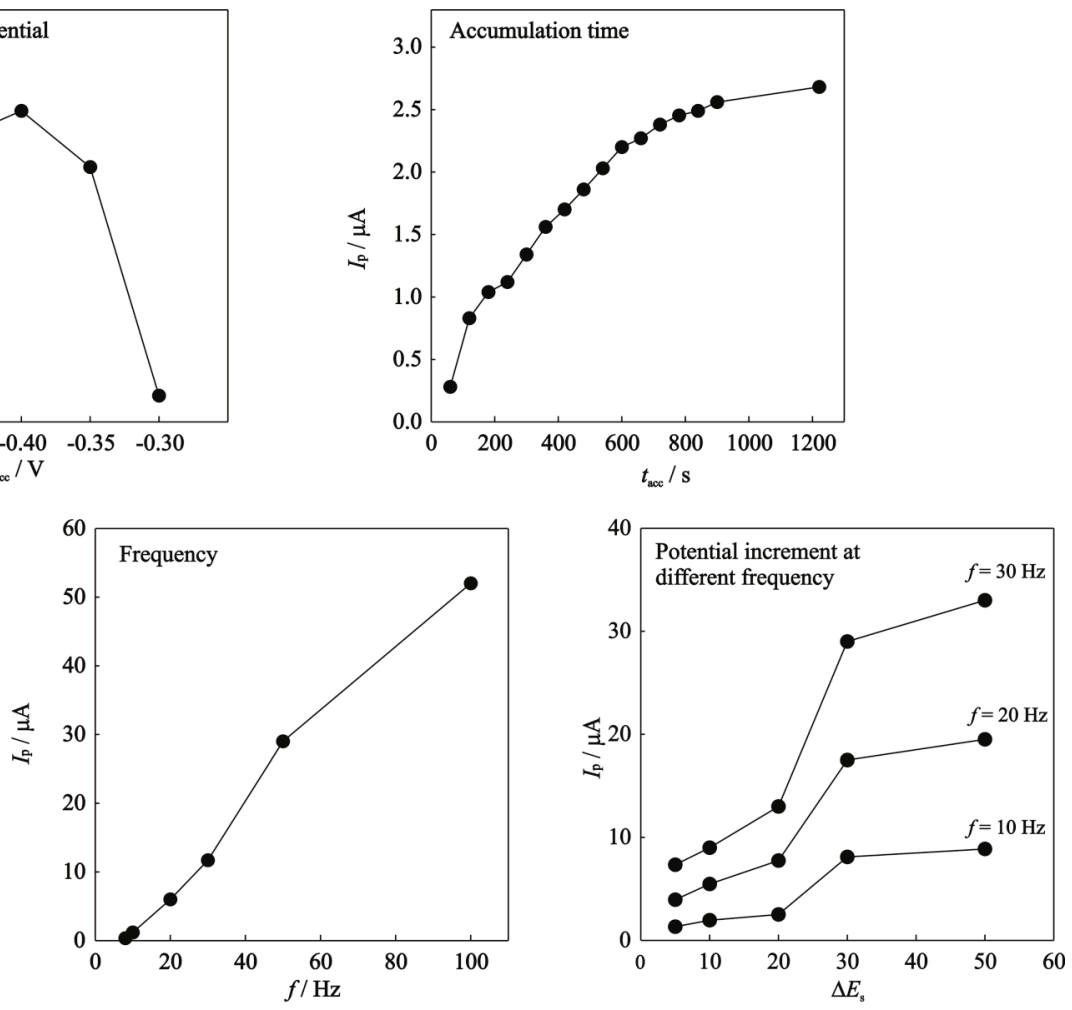

Figure 4. Effect of the electrochemical parameters on reduction peak current for SWCSV on BiFE in 0.1 mol L-1 acetate buffer solution ( $\mathrm{pH}$ 4.5) containing $1.0 \mu \mathrm{mol} \mathrm{L-1} \mathrm{FA}$. Optimizing time and potential accumulation was carried out with $f=10 \mathrm{~Hz}, \Delta E_{\mathrm{s}}=$ $20 \mathrm{mV}$ and $\Delta E_{\mathrm{p}}=100 \mathrm{mV}$.
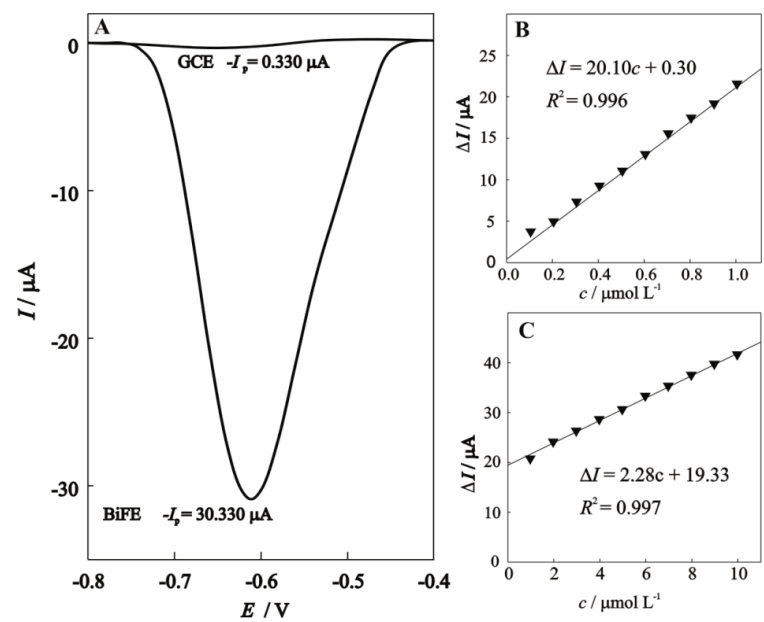

Figure 5. (A) SWCSVs with baseline correction, recorded at GCE and BiFE in $0.1 \mathrm{~mol} \mathrm{~L}^{-1}$ acetate buffer solution ( $\mathrm{pH} 4.5$ ) in the presence of $5.0 \mu \mathrm{mol} \mathrm{L}^{-1} \mathrm{FA}$; (B) calibration plot derived by subtracting background current from corresponding voltammograms for concentrations range 0.1-1.0 $\mu \mathrm{mol} \mathrm{L}^{-1}$; (C) calibration plot derived by subtracting background current from corresponding voltammograms for concentration range $1.0-10.0 \mu \mathrm{mol} \mathrm{L} \mathrm{L}^{-1}$.
$30 \mathrm{~Hz}$ ) suffered from the lack of reproducibility and precision (due to the inability for obtaining sufficient number of points). According above, for working frequency $30 \mathrm{~Hz}$, together with $\Delta E_{\mathrm{s}}=20 \mathrm{mV}$ were chosen. Thus, all subsequent SWCSV were carried out with: $E_{\mathrm{acc}}=-0.4 \mathrm{~V}, t_{\mathrm{acc}}=180 \mathrm{~s}, f=$ $30 \mathrm{~Hz}, \Delta E_{\mathrm{s}}=20 \mathrm{mV}$ and $\Delta E_{\mathrm{p}}=100 \mathrm{mV}$.

In the Figure 5.A comparable SWCS voltammograms of the reduction of folic acid at the bare GCE and BiFE are shown. As it can be seen, at optimized condition, BiFE shows high sensitivity for FA compared to bare GCE. This difference in electrochemical behavior can be attributed to the lack of the accumulation (physical adsorption) of FA onto GCE. Also, slightly shift of the reduction potential of the FA (on BiFE) toward negative values, compared to the reduction potential observed by cyclic voltammetry (see Figure 2.), can be attributed to the kinetic limitation of the FA reduction at optimized parameters of SWCSV.

Figure 5.B and 5.C represent calibration plots derived by subtracting background current from corresponding voltammograms (not shown).

As it can be seen from Figure $5 B$ and $5 C$, two different linear ranges were obtained, both with good linearity $\left(R^{2}=0.996\right.$ and 0.997$)$ and with sensitivity of $20.10 \mu \mathrm{A} \mathrm{mol}^{-1} \mathrm{~L}$ and $2.28 \mu \mathrm{A} \mu \mathrm{mol}^{-1} \mathrm{~L}$ for concentrations 
ranges $0.1-1.0 \mu \mathrm{mol} \mathrm{L}^{-1}$ and $1.0-10.0 \mu \mathrm{mol} \mathrm{L}^{-1}$, respectively. The calculated limit of detection (LOD) of FA, based on the $3 \sigma$ criterion, ${ }^{[44]}$ obtained from the slope of the analytical curve, was $0.001 \mu \mathrm{mol} \mathrm{L} \mathrm{L}^{-1}$. The limit of detection is given as $\mathrm{LOD}=3 \times \mathrm{SD} / b$, where $\mathrm{SD}$ is the standard deviation of 10 measurements of a blank solution and $b$ is the

Table 1. Comparison of the analytical performances, reported for the electrochemical determination of FA with our work.

\begin{tabular}{|c|c|c|c|c|c|c|}
\hline Methods & Modification & $\mathrm{pH}$ & $\begin{array}{l}\text { Linear range/ } \\
\mu \mathrm{mol} \mathrm{L}\end{array}$ & $\begin{array}{c}\mathrm{LOD} / \\
\mu \mathrm{mol} \mathrm{L} \\
\end{array}$ & $\begin{array}{l}\text { Samples } \\
\text { analysed }\end{array}$ & Reference \\
\hline AC-AdSV & Static mercury drop electrode & 5.0 & $1 \times 10^{-2}-5 \times 10^{-5}$ & $2 \times 10^{-6}$ & N/A & {$[16]$} \\
\hline $\begin{array}{l}\text { DPP } \\
\text { DPASV }\end{array}$ & Carbon paste electrode modified with palmitic/stearic acid & 7.4 & $6 \times 10^{-3}-600$ & $4 \times 10^{-3}$ & with $\mathrm{Pb}$ and $\mathrm{Cd}$ & {$[47]$} \\
\hline CV and LSV & Singlewall carbon nanotubes /glassy carbon electrode & 5.5 & $0.01-100$ & $1 \times 10^{-3}$ & N/A & {$[48]$} \\
\hline CA and $\mathrm{CC}$ & Multiwall carbon nanotubes/Au & 2.5 & $0.02-1$ & 0.01 & Ph. Form. & [49] \\
\hline DPV & $\left(\mathrm{PMo}_{12}\right)$ doped polypyrrole film & 2.0 & $0.01-0.1$ & $1 \times 10^{-4}$ & N/A & {$[50]$} \\
\hline ASV & In situ lead film electrode/glassy carbon electrode & 5.6 & $2 \times 10^{-3}-0.08$ & $7 \times 10^{-4}$ & Ph. Form. & {$[51]$} \\
\hline DPASV & Calixarene modified carbon paste electrode & 4.0 & $8.79 \times 10^{-6}-\times 10^{-3}$ & $1.2 \times 10^{-6}$ & $\begin{array}{l}\text { vegetables and } \\
\text { fruits }\end{array}$ & {$[52]$} \\
\hline DPV & $\begin{array}{l}\text { Singlewall carbon nanotubes electrode with ionic liquid } \\
\text { paste }\end{array}$ & 5.5 & $2 \times 10^{-3}-4.0$ & $1 \times 10^{-3}$ & $\begin{array}{c}\text { wheat flour, } \\
\text { fruit juices, } \\
\text { milk }\end{array}$ & {$[53]$} \\
\hline DPCSV & $\begin{array}{l}\text { Graphite pencil electrode/Molecularly imprinted polymer- } \\
\text { immobilized sol-gel-modified }\end{array}$ & 7.8 & $\begin{array}{c}5 \times 10^{-3}- \\
0.156 \mu \mathrm{g} \mathrm{mL}-1\end{array}$ & $3.6 \times 10^{-6}$ & blood serum & {$[54]$} \\
\hline DPV & Carbon paste electrode with $\mathrm{ZrO}_{2}$ nanoparticles & 7.0 & $20-2500$ & 9.86 & $\begin{array}{l}\text { mixture of FA, } \\
\text { norepinerin, } \\
\text { paracetamol }\end{array}$ & {$[55]$} \\
\hline CV and DPV & $\begin{array}{l}\text { Carbon paste electrode modified with hydroquinone } \\
\text { derivates }\end{array}$ & 7.0 & $200-3200$ & 25 & $\begin{array}{l}\text { mixture of FA, } \\
\text { norepinerin, } \\
\text { paracetamol }\end{array}$ & {$[56]$} \\
\hline DPV & Mercury free Ag amalgam electrode & 5.0 & $1 \times 10^{-3}-4.0$ & $588 \times 10^{-6}$ & Ph. Form. & [57] \\
\hline $\mathrm{CV}$ & $\begin{array}{l}\text { Multiwall carbon nanotubes / polivinilsulfonic acid on glassy } \\
\text { carbon electrode }\end{array}$ & 7.0 & $53-1700$ & $\mathrm{~N} / \mathrm{A}$ & N/A & {$[58]$} \\
\hline CV and DPV & Mesoporous carbon/graphite electrode & 7.0 & $5.0-2000$ & 0.7 & $\begin{array}{c}\text { mixture of FA, } \\
\text { norepinerin, } \\
\text { paracetamol }\end{array}$ & [59] \\
\hline $\begin{array}{l}\text { Voltammet } \\
\text { ry }\end{array}$ & $\begin{array}{l}\text { Carbon nanotube paste modified with ferrocen carboxylic } \\
\text { acid }\end{array}$ & 5.0 & $0.10-750$ & $65 \times 10^{-3}$ & urine & {$[60]$} \\
\hline DPV & Mercury film electrode & 7.1 & $\begin{array}{c}0.13-1 \\
2-10\end{array}$ & $14 \times 10^{-3}$ & Ph. Form. & {$[61]$} \\
\hline DPV & $\begin{array}{l}\text { Au electrode modified with } \\
\text { Au nanoparticles }\end{array}$ & 14 & $0.01-1.0$ & $7.5 \times 10^{-3}$ & $\begin{array}{l}\text { Ph. Form, flour, } \\
\text { spinach }\end{array}$ & {$[62]$} \\
\hline CV and DPV & Glassy carbon electrode modified with $\mathrm{PMO}_{12} / \mathrm{PPy} / \mathrm{GR}$ & 2.0 & $0.001-0.2$ & $3.3 \times 10^{-4}$ & N/A & {$[63]$} \\
\hline $\begin{array}{l}\text { CV and } \\
\text { SWCSV }\end{array}$ & Boron doper diamond electrode & $\begin{array}{l}1.0 \\
6.0\end{array}$ & $\begin{array}{l}0.23-4.5 \\
2.3-90\end{array}$ & $\begin{array}{c}0.0793 \\
0.32\end{array}$ & Ph. Form. & {$[64]$} \\
\hline $\begin{array}{l}\text { CV, CA and } \\
\text { SWV }\end{array}$ & $\begin{array}{l}\text { ZnO nanoparticle modified ionic liquid-carbon paste } \\
\text { electrode }\end{array}$ & 9.0 & $0.05-550$ & 0.01 & $\begin{array}{c}\text { Ph. Form, } \\
\text { urine, apple } \\
\text { juice }\end{array}$ & {$[65]$} \\
\hline $\begin{array}{l}\text { CV and } \\
\text { SWCSV }\end{array}$ & Bismuth nanowires/glassy carbon electrode & 4.5 & $0.01-0.15$ & $9.53 \times 10^{-3}$ & Ph. Form. & [38] \\
\hline SWV & $\begin{array}{l}\text { Chemically modified Carbon paste electrode modified } \\
\mathrm{ZnO} / \text { Carbon nanotubes nanocomposite electrode }\end{array}$ & 7.0 & $3-700$ & 1 & $\begin{array}{l}\text { Ph. Form. } \\
\text { urine, human } \\
\text { blood, }\end{array}$ & {$[66]$} \\
\hline LSV, CV, A & $\begin{array}{c}\text { Carbon nanohorns supported interwoven titanate } \\
\text { nanotubes }\end{array}$ & 6.0 & $1 \times 10^{-4}-50$ & $25 \times 10^{-6}$ & Ph. Form., oats & {$[67]$} \\
\hline $\begin{array}{l}\text { EIS, CV, and } \\
\text { SWV }\end{array}$ & $\begin{array}{l}\mathrm{Mn} \text { doped } \mathrm{SnO}_{2} \text { nanoparticles (NPs) modified glassy carbon } \\
\text { electrode }\end{array}$ & 7.0 & $1-500$ & 0.038 & Ph. Form & {$[68]$} \\
\hline $\begin{array}{l}\text { CV and } \\
\text { SWCSV }\end{array}$ & Bismuth film/glassy carbon electrode deposited with EDTA & 4.5 & $0.1-10.0$ & $1 \times 10^{-3}$ & Ph. Form & This work \\
\hline
\end{tabular}


analytical sensitivity. This value is comparable with values reported by other researchers for determination of FA at the surface of chemically modified electrodes (Table 1 ).

The excellent reproducibility of this method has been determined by the measurement of the current responses toward FA on three formed BiFEs. Also, relative standard deviation of ten consequent measurements, in solutions containing $2.0 \mu \mathrm{mol} \mathrm{L}-1$, was $1.4 \%$.

The change in slope, with linearity preserving, can be attributed to the increased amount of folic acid accumulated at electrode surface, resulting in saturation of electrode surface, as it was reported for the determination of cysteine on $\mathrm{Hg}{ }^{[45,33]}$ However, this will not take effect on analytical capabilities since these ranges are well defined and reproducible, although some authors ${ }^{[46]}$ suggest employing of shorter accumulation time at higher analyte concentrations.

The determination of FA was found to be strongly affected in the presence of glutathione, cysteine and $\mathrm{N}$-acetyl cysteine owing to presence of thiol group in these molecules, which is known to have high affinity for bismuth. ${ }^{[33,40]}$ SWCS voltammograms (not shown), in the presence of these thiols, exhibit wider, less defined reduction peak, obviously as a consequence of simultaneous reduction of presented species on BiFE. However, this can be prevented by manipulation of accumulation time and accumulation potential of FA. Also, no interferences were observed in the presence of the substances that can be found in pharmaceutical formulations: lactose monohydrate, microcrystalline cellulose, magnesium stearate, crospovidone and povidone.

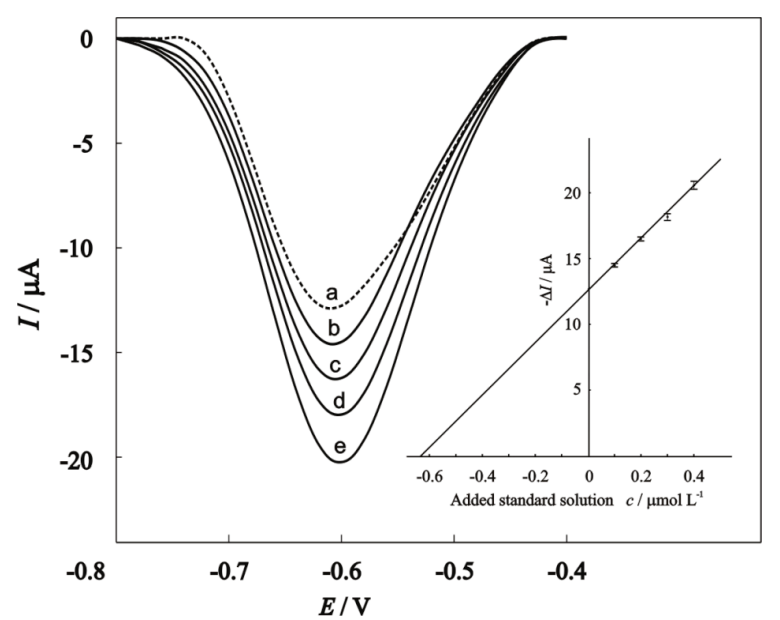

Figure 6. Analytical determination and recovery studies of FA in $0.1 \mathrm{~mol} \mathrm{~L}^{-1}$ acetate buffer solution ( $\mathrm{pH} \mathrm{4.5)}$ at BiFE under optimized conditions for food supplement (Folacin) solution. Concentration of FA standard solution added: (a) supplement solution, (b) $0.10 \mu \mathrm{mol} \mathrm{L}^{-1}$ (c) $0.20 \mu \mathrm{mol} \mathrm{L^{-1 }}$ (d) $0.30 \mu \mathrm{mol} \mathrm{L}^{-1}$ (e) $0.40 \mu \mathrm{mol} \mathrm{L} \mathrm{L}^{-1}$.
Obtained analytical performance by proposed method are comparable with values reported by other research groups (see Table 1). As it can be seen, the presented method showed satisfactory analytical performance. Although this method can not be recommended for determination of FA in serum (concentration of folic acid in human serum is around $0.10-0.01 \mu \mathrm{mol} \mathrm{L^{-1 }}$ ), in further experiment (see Analytical application) we proved that it is suitable as analytical tool for determination of FA in pharmaceutical formulations.

\section{Analytical Application in Pharmaceutical Sample}

The analytical performance of the prepared BiFE was evaluated by determination of folic acid in Folacin tablets. In voltammetric cell $95 \mathrm{~mL}$ of acetic buffer solution was spiked with $5 \mathrm{~mL}$ of supplement solution. The concentration of FA in such prepared solution, determined with adopted spectrophotometric method, ${ }^{[41]}$ was $0.63 \mu \mathrm{mol} \mathrm{L}^{-1}$.

Electroanalytical determination of FA and recovery experiments was performed using established SWCSV procedure by standard addition method (concentration step of FA standard solution was $0.1 \mu \mathrm{mol} \mathrm{L^{-1 }}$ ). The resulting voltammograms showed well-defined reduction stripping peaks and the standard addition plots were linear, as can be seen in Figure 6. The concentration of the folic acid was calculated from difference of the obtained peak currents (Figure 6). Four additions of FA standard solution to the sample yielded recoveries in the range of 95.5 to $103.0 \%$.

Additionally, the pharmaceutical formulations containing FA were independently analyzed with adopted spectrophotometric method. ${ }^{[41]}$ The comparative results obtained by these methods are given in Table 2 .

Using the proposed method relative standard deviation (RSD) of the mean of three determinations of FA sample was lower than $3.0 \%$. Also, the relative error between methods, within $97 \%$ of confidence level, indicated that proposed method can be successfully applied for FA determination in food supplement.

Table 2. Reproducibility of proposed electrochemical method and its comparison with adopted spectrophotometric method.

\begin{tabular}{ccccc}
\hline Tablets & $\begin{array}{c}\text { Labeled } \\
\text { value / } \\
\text { mg tablet }^{-1}\end{array}$ & $\begin{array}{c}\text { Spectropho- } \\
\text { tometric } \\
\text { Analysis }\end{array}$ & $\begin{array}{c}\text { Proposed } \\
\text { Electrochemi- } \\
\text { cal Method }\end{array}$ & $\begin{array}{c}\text { Relative } \\
\text { errors / } \\
\%\end{array}$ \\
\cline { 3 - 5 } 1 & 5.000 & 5.020 & 4.967 & 1.056 \\
2 & 5.000 & 5.021 & 4.888 & 2.649 \\
3 & 5.000 & 5.022 & 5.170 & 2.947 \\
\hline Relative error $\mid=[($ SWCSV - Spectrophotometric) / Spectrophotometric] $\times$
\end{tabular}

$100 \%$. 


\section{CONCLUSION}

The BiF formed in acetate buffer, in the presence of EDTA at optimized condition, show electrocatalytical nature toward folic acid reduction which can be attributed to the reduction of nitrogen from pteridine part.

This behavior was utilized to establish a novel electrochemical procedure for quantitative determination of FA. The method is based on selective physical adsorption of FA onto BiF followed by its reduction using SWCSV.

Analytical calibration curve was characterized with two linear ranges: $0.1 \mu \mathrm{mol} \mathrm{L^{-1 }}$ up to $1.0 \mu \mathrm{mol} \mathrm{L^{-1 }}$ and

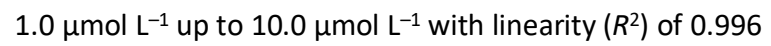
and 0.997, respectively. Obtained detection limit was $0.001 \mu \mathrm{mol} \mathrm{L}^{-1}$, with relative standard deviation of $1.4 \%$.

Analysis of the authentic samples containing FA, showed no interference from additives and excipients presented in pharmaceutical formulations. Consequently, a proposed method was successively applied for the analysis of folic acid in tablets with satisfactory recoveries (from 95.5 to $103.0 \%)$.

Adopted spectrophotometric method was used to validate proposed method. The obtained results show a satisfactory matching in the selected ranges.

Due to a non-toxic character of BiFE, simple procedure and analytical performances, this method is advantageous when compared with other reported studies.

\section{REFERENCES}

[1] World Health Organization, Food and Agricultural Organization of the United Nations: Vitamin and mineral requirements in human nutrition, $2^{\text {nd }} \mathrm{Ed}$. Geneva, 2004, pp. 289-294.

[2] R. Iyer, S. K. Tomar, J. Food Sci. 2009, 74, 14.

[3] H. J. Bloom, Y. Smulders, J. Inherit. Metab. Dis. 2011, $34,75$.

[4] S. Yakubu, J. Muazu, Der Pharm. Sinica, 2010, 1, 55.

[5] J. Le Boucher, C. Charret, C. Coudray-Lucas, J. Giboudeau, L. Cynober, Clin. Chem. 1997, 43, 1421.

[6] M. H. Joseph, P. Davies, J. Chromatogr. B: Biomed. Sci. App. 1983, 277, 125.

[7] D. Fekkes, J. Chromatogr. B: Biomed. Sci. Appl. 1996, 682, 3.

[8] A. Pappa-Louisi, P. Nikitas, P. Agrafiotou, A. Papageorgiou, Anal. Chim. Acta 2007, 593, 92.

[9] M. Armstrong, K. Jonscher, N.A. Reisdorph, Rapid Commun. Mass Spectrom. 2007, 21, 2717.

[10] M. Piraud, C. Vianey-Saban, K. Petritis, C. Elfakir, J. Steghens, D. Bouchu, Rapid Commun. Mass Spectrom. 2005, 19, 1587.

[11] T. Soga, Y. Kakazu, M. Robert, M. Tomita, T. Nishioka, Electrophoresis 2004, 25, 1964.
[12] R. Matias, P. R. S. Ribeiro, M.C. Sarraguça, J. A. Lopes, Anal. Methods 2014, 6, 3065.

[13] S. M. Wabaidur, S. M. Alam, S. H. Lee, Z. A. Alothman, G. E. Eldesoky, Spectrochim. Acta Mol. Biomol. Spectrosc. 2013, 15, 412.

[14] C. Cruces Blanco, A. Segura Carretero, A, Fernández Gutiérrez, M. Román Ceba, Anal. Lett. 1994, 27, 1339.

[15] L. Mirmoghtadaie, N. Shamaeizadeh, N. Mirzanasiri, Int. J. Preventive Medicine 2015, 6, 100.

[16] J. Han, H. Chen, H. Gao, Anal. Chim. Acta 1991, 252, 47.

[17] J. M. F. Alvarez, A.C. Garcia, A. J. M. Ordieres, P. T. Blanco, J. Electroanal. Chem. 1987, 225, 241.

[18] A.-C. Le Gall, C. M. G. van den Berg, Anal. Chim. Acta 1993, 282, 459.

[19] L. Bandzuchova, R. Selesovska, Acta Chim. Slov. 2011, 58, 776.

[20] J. Wang, Electroanal. 2005, 17, 134.

[21] A. Economou, TrAC 2005, 24, 334.

[22] N. Lezi, V. Vyskočil, A. Economou, J. Barek, Sensing in electroanalysis 2012, 7, 71.

[23] J. Cai, X. Zhou, Y. Tu, G. Feng, C. Huang, Adv. Mat. Lett. 2012, 3, 87.

[24] V. Guzsvány, M. Kádár, F. Gaál, L. Bjelica, K. Tóth, Electroanalysis 2006, 18, 1363.

[25] V. Guzsvány, M. Kádár, Z. Papp, L. Bjelica, F. Gaál, K. Tóth, Electroanalysis 2008, 20, 291.

[26] V. Guzsvány, Z. Papp, J. Zbiljic, O. Vajdle, M. Rodic, Molecules 2011, 16, 4451.

[27] S. Daniele, D. Battistel, S. Bergamin, C. Bragato, Electroanal. 2010, 22, 1511.

[28] G. L. Kreft, O. C. de Braga, A. Spinelli, Electrochim. Acta 2012, 83, 125.

[29] H. Duwensee, M. Adamovski, G. U. Flechsig, Int. J. Electrochem. Sci. 2007, 2, 498.

[30] H. Sopha, S.B. Hocevar, B. Pihlar, B. Ogorevc, Electrochim. Acta 2012, 60, 274.

[31] B. Nigovic, B. Simunic, S. Hocevar, Electrochim. Acta 2009, 54, 5678.

[32] I. Campestrini, O.C. de Braga, I.C. Vieira, A. Spinelli, Electrochim. Acta 2010, 55, 4970.

[33] S. Brinic, N. Vladislavic, M. Buzuk, M. Bralic, M. Solic, J. Electroanal. Chem. 2013, 705, 86.

[34] L. C. S. Figueiredo-Filho, V. B. dos Santos, B. C. Janegitz, T. B. Guerreiro, O. Fatibello-Filho, R. C. Faria, L. H. Marcolino-Junior, Electroanal. 2010, 22, 1260.

[35] L. C. S. Figueiredo-Filho, D. C. Azzi, B. C. Janegitz, O. Fatibello-Filho, Electroanal. 2012, 24, 303.

[36] E. A. Hutton, B. Ogorevc, M. R. Smyth, Electroanal. 2004, 16, 1616.

[37] U. Anık, S. Timur, M. Cubukcu, A. Merkoci, Microchim. Acta 2008, 160, 269. 
[38] A. Ananthi, S. S. Kumar, K. L. Phani, Electrochim. Acta 2015, 151, 584.

[39] P. Kalimuthu, S.A. John, Biosens. Bioelectron. 2009, 24, 3575.

[40] N. Vladislavić, M. Buzuk, S. Brinić, M. Buljac, M. Bralić, J. Solid State Electr. 2016, 20, 2241.

[41] P. Nagaraja, R.A. Vasantha, H.S. Yathirajan, Anal. Biochem. 2002, 307, 316.

[42] B. D. Lawrence, S. Wharram, J. A. Kluge, G. G. Leisk, F. G. Omenetto, M. I. Rosenblatt, D. L. Kaplan, Macromol. Biosci. 2010, 10, 393.

[43] E. V. Dorozhko, E. I. Korotkova, A. A. Shabaeva, A. Y. Mosolkov, Procedia Chem. 2015, 15, 365.

[44] J. Mocak, A.M. Bond, S. Mitchell, G. Scollary, Pure \& Applied Chemistry 1997, 69, 297.

[45] R. von Wandruszka, X. Yuan, M.J. Morra, Talanta 1993, 40, 37.

[46] L. Baldrianova, P. Agrafiotou, I. Svancara, K. Vytras, S. Sotiropoulos, Electrochem. Commun. 2008, 10, 918.

[47] N. A. El-Maali, Bioelectroch. Bioener. 1992, 27, 465.

[48] C. Wang, C. Li, L. Ting, X. Xu, C. Wang, Microchim. Acta 2006, 152, 233.

[49] S. Wei, F. Zhao, Z. Xu, B. Zeng, Microchim. Acta 2006, 152, 285.

[50] H. X. Guo, Y. Q. Li, L. F. Fan, X. Q. Wu, M. D. Guo, Electrochim. Acta 2006, 51, 6230.

[51] M. Korolczuk, K. Tyszczuk, Electroanal. 2007, 19, 1959.

[52] V. D. Vaze, A. K. Srivastava, Electrochim. Acta 2007, 53, 1713.

[53] F. Xiao, C. Ruan, L. Liu, R. Yan, F. Zhao, B. Zeng, Sens. Actuator B-Chem. 2008, 134, 895.

[54] B. B. Prasad, M. P. Tiwari, R. Madhuri, P. S. Sharma, Anal. Chim. Acta 2010, 662, 14.
[55] M. Mazloum-Ardakani, H. Beitollahi, M. K. Amini, F. Mirkhalaf, M. Abdollahi-Alibeik, Sens. Actuator BChem. 2010, 151, 243.

[56] M. Mazloum-Ardakani, H. Beitollahi, M. A. Sheikh-Mohseni, H. Naeimi, N. Taghavinia, Appl. Catal. A:General 2010, 378, 195.

[57] L. Bandzuchova, R. Šelešovská, T. Navrátil, J. Chy'lková, Electrochim. Acta 2011, 56, 2411.

[58] B. Unnikrishnan, Y. L. Yang, S. M. Chen, Int. J. Electrochem. Sci. 2011, 6, 3224.

[59] M. Mazloum-Ardakani, M. A. Sheikh-Mohseni, M. Abdollahi-Alibeik, A. Benvidi, Sens. Actuator BChem. 2012, 171-172, 380.

[60] S. E. Baghbamidi, H. Beitollahi, H. Karimi-Maleh, S. Soltani-Nejad, V. Soltani-Nejad, S. Roodsaz, J. Anal. Methods Chem. 2012, 1.

[61] P. A. M. Farias, M. de Castro Rezende, J.C. Moreira, IOSR J. Pharm. 2012, 2, 302.

[62] L. Mirmoghtadaie, A.A. Ensafi, M. Kadivar, M. Shahedi, M.R. Ganjali, Int. J. Electrochem. Sci. 2013, 8, 3755 .

[63] Z. Wang, Q. Han, J. Xia, L. Xia, S. Bi, G. Shi, F. Zhang, Y. Xia, Y. Li, L. Xia, J. Electroanal. Chem. 2014, 726, 107.

[64] Y. Yardim, Z. Sentürk, Turkish J. Pharm. Sci. 2014, 11, 87.

[65] A. Taherkhani, T. Jamali, H. Hadadzadeh, H. KarimiMaleh, H. Beitollahi, M. Taghavi, F. Karimi, lonics 2014, 20, 421.

[66] J. B. Raoof, N. Teymoori, M. A. Khalilzadeh, R. Ojani, Mater. Sci. Eng.C 2015, 47, 77.

[67] H. Dai, Y. Li, S. Zhang, L. Gong, X. Li, Y. Lin, Sens. Actuator B-Chem. 2016, 222, 120.

[68] N. Lavanya, E. Fazio, F. Neri, A. Bonavita, S. G. Leonardi, G. Neri, C. Sekar, J. Electroanal. Chem. 2016, 770, 23. 